\title{
HUBUNGAN PERAN FUNGSI PETUGAS KESEHATAN \\ DENGAN KEPATUHAN MINUM OBAT PADA PASIEN \\ DIABETES MELITUS TIPE 2 DI WILAYAH KERJA \\ PUSKESMAS GANG SEHAT PONTIANAK
}

\section{The Correlation Between The Role Of The Function Of Health Workers And Taking Medicine Compliance In Patients With Type 2 Diabetes Mellitus In The Working Area Of The Community Health Center Of Gang Sehat Pontianak}

\author{
Suriyani Nengsih Permatasari*, Mita**, Herman*** \\ *Mahasiswi Prodi Keperawatan Fakultas Kedokteran Universitas Tanjungpura Pontianak, \\ suriyaninengsihpermatasari@student.untan.ac.id \\ **Dosen Keperawatan Fakultas Kedokteran Universitas Tanjungpura Pontianak, mita@ners.untan.ac.id \\ *** Dosen Keperawatan Fakultas Kedokteran Universitas Tanjungpura Pontianak, herman@ners.untan.ac.id
}

\begin{abstract}
ABSTRAK
Latar Belakang: Dalam mengontrol perjalanan penyakit diabetes melitus ada 5 pilar penting penatalaksanaan nya yaitu edukasi, pola makan, olahraga, famakologi dan pemantauan gula darah. Dalam pengobatan penyakit diabetes melitus timbul masalah ketidakpatuhan. Dukungan tenaga kesehatan sangat diperlukan untuk meningkatkan kepatuhan. Petugas kesehatan merupakan orang pertama yang mengetahui tentang kondisi kesehatan pasien, sehingga memiliki peran yang besar dalam menyampaikan informasi pada pasien.

Tujuan: Untuk mengetahui hubungan peran fungsi petugas kesehatan dengan kepatuhan minum obat pada pasien diabetes melitus tipe 2 di wilayah kerja Puskesmas Gang Sehat Pontianak.

Metode: Penelitian kuantitatif menggunakan desain cross sectional. Teknik sampling yaitu purposive sampling dengan jumlah responden 101 orang.

Hasil: Peran fungsi petugas kesehatan baik dan kepatuhan minum obat antidiabetes kurang patuh. Analisa bivariat dengan uji chi square didapatkan nilai $p=0,278(p>0,05)$.

Kesimpulan: Tidak terdapat hubungan peran fungsi petugas kesehatan dengan kepatuhan minum obat pada pasien diabetes melitus tipe 2 di Wilayah Kerja Puskesmas Gang Sehat Pontianak.
\end{abstract}

Kata Kunci: DM Tipe 2, Kepatuhan Minum Obat, Peran Fungsi Petugas Kesehatan 


\begin{abstract}
Background: In controlling the course of the disease, there are 5 important pillars for managing type 2 diabetes melitus patients, such as education, diet, exercise, pharmacology and monitoring blood sugar. In the treatment of diabetes mellitus, problems to know about the patient's health condition, so that they have a big role in conveying information to patients.

Objective: To determine the correlation between the role of the function of health workers and taking medicine compliance in patients with type 2 diabetes mellitus in the working area of the community health Center of gang sehat pontianak.

Method: This study used quantitative research with cross sectional design. The sampling technique employed was purposive sampling method with a total sample of 101 respondents. The research data was analyzed using the chi-square statistical test.

Results: Based on the respondents' characteristics, the majority of patients were $>65$ years old (43.6\%), female (62.4\%), junior high school education background (33.7\%), and had a working status as a housewife (41.6\%), had medication education (94.1\%), and got family support (61.4\%). While the role of health staffs' function was good (65.4\%), but medication non-compliance $(56.4 \%)$, and $p$ value $=0.278(p>0.05)$.

Conclusion: There is no correlation between the role of the function of health workers and taking medicine compliance in patients with type 2 diabetes mellitus in the Working Area of community health center of Gang Sehat Pontianak.
\end{abstract}

Keywords: DM Type 2, taking medicine compliance, Role of Health workers' Function 


\section{PENDAHULUAN}

Perkumpulan

Endokrinologi

Indonesia menyatakan ada 5 pilar penting penatalaksanaan pasien diabetes melitus tipe 2 yaitu edukasi, pola makan, olahraga, famakologi dan pemantauan gula darah. Terapi farmakologi diberikan bersama dengan pengaturan makan dan latihan jasmani (gaya hidup sehat) ${ }^{8}$. American Diabetic Association (ADA) (2013) menyatakan terapi farmakologis terdiri dari obat oral dan bentuk suntikan. Obat hipoglikemik oral, berdasarkan cara kerjanya, OHO dibagi menjadi 5 golongan yaitu pemicu sekresi insulin sulfonylurea dan glinid, peningkat sensitivitas terhadap insulin metformin dan tiazolidindion, penghambat glukoneogenesis, penghambat absorpsi glukosa: penghambat glukosidase alfa dan DPPIV inhibitor ${ }^{3}$.

Hasil Riset Kesehatan Dasar (Riskesdas) tahun 2018 presentasi pasien yang rutin dalam minum OAD dan suntik insulin sebanyak $91 \%$ dan yang tidak rutin sebanyak 9\%. Alasan pasien tidak rutin disebabkan karena pasien itu sendiri merasa sudah sehat, tidak rutin berobat ke fasyankes, minum obat tradisional, sering lupa, penyebab lainnya, tidak tahan efek samping obat, tidak mampu membeli obat secara rutin, obat tidak tersedia di fasyankes ${ }^{4}$.

Hasil studi pendahuluan di Puskesmas Gang Sehat didapatkan jumlah pasien diabetes melitus tipe 2 yang melakukan kunjungan di Puskesmas Gang Sehat pada tahun 2018 sebanyak 6,1\% dari jumlah estimasi penderita diabetes melitus sebanyak 313 orang. Berdasarkan data yang diperoleh dari petugas kesehatan Puskesmas Gang Sehat. bahwa masih ada pasien diabetes melitus yang melakukan kontrol gula darah tidak teratur.

.Faktor- faktor yang berhubungan dengan kepatuhan berobat pasien diabetes melitus yaitu pengetahuan, sikap, dan motivasi. Pasien yang memiliki pengetahuan yang baik akan patuh jika dibandingkan dengan pasien dengan pengetahuan yang kurang baik. Sikap pasien juga berhubungan dengan kepatuhan berobat, pasien yang memiliki sikap yang baik akan patuh jika dibandingkan dengan pasien dengan sikap kurang baik. Kemudian, motivasi pasien berhubungan dengan kepatuhan berobat, motivasi yang baik akan patuh dibandingkan dengan motivasi yang kurang baik. Motivasi ini didasarkan pada informasi yang di dapat serta hasil pengamatan suatu objek sehingga menimbulkan persepsi untuk berbuat atau melakukan sesuatu ${ }^{4}$. Selain pengetahuan, sikap, dan motivasi ada faktor lain yang dapat mempengaruhi kepatuhan minum obat, yaitu interaksi pasien dengan tenaga kesehatan ${ }^{6}$.

Dukungan tenaga kesehatan sangat diperlukan untuk meningkatkan kepatuhan, misalnya dengan adanya komunikasi. Hal ini sesuai dengan teori yang ada, dimana petugas kesehatan merupakan orang pertama yang mengetahui tentang kondisi kesehatan pasien sehingga mereka memiliki peran yang besar dalam menyampaikan informasi mengenai kondisi kesehatan dan hal-hal yang harus dilakukan oleh pasien untuk proses kesembuhannya. Komunikasi ini dapat dilakukan melalui pendidikan kesehatan berupa penyuluhan ${ }^{7}$.

Apabia pasien diabates melitus pernah mendapat informasi dari tenaga kesehatan maka akan meningkatkan perilaku kesehatan, informasi yang diperoleh akan meningkatkan pengetahuan dan hal tersebut akan mempengaruhi kepatuhan dalam menjalani terapi diabetes melitus ${ }^{8}$.

Berdasarkan data di atas, peneliti tertarik untuk melakukan penelitian tentang "hubungan peran fungsi petugas kesehatan dengan kepatuhan minum obat pada pasien diabetes melitus tipe 2 di wilayah kerja Puskesmas Gang Sehat Pontianak"

\section{METODE}

Penelitian ini merupakan penelitian kuantitatif observasional analitik dengan 
hipotesis komparatif. Desain yang digunakan dalam penelitian ini adalah Cross Sectional dengan jumlah responden sebanyak 101 pasien yang menderita diabetes melitus tipe 2 di Wilayah kerja Puskesmas Gang Sehat Pontianak.

Instrumen yang digunakan pada penelitian ini adalah kuesioner peran fungsi petugas kesehatan terdiri 16 pertanyaan yang sudah diuji validitas dan kuesioner Morisky Medication Adherance Scale (MMAS-8) terdiri atas 8 pertanyaan.

Analisa data pada penelitian ini menggunakan analisis statistik komputer. Setelah data terkumpul kemudian dilakukan pengelolaan data dengan menggunakan Uji Chi-Square dengan penarikan kesimpulan akhir menggunakan nilai $p$ value.

\section{HASIL}

\section{Distribusi Karakteristik Responden}

Tabel 1. Karakteristik Responden Berdasarkan Usia, Jenis Kelamin, Pendidikan, pekerjaan, edukasi minum obat dan dukungan keluarga $(n=101)$.

\begin{tabular}{|c|c|c|}
\hline Karakteristik & $\begin{array}{l}\text { Frekuensi } \\
\text { (f) }\end{array}$ & $\begin{array}{c}\text { Persentase } \\
(\%)\end{array}$ \\
\hline \multicolumn{3}{|l|}{ Usia } \\
\hline $\begin{array}{l}\text { Dewasa akhir (36-45 } \\
\text { tahun) }\end{array}$ & 8 & 7,9 \\
\hline $\begin{array}{l}\text { Lansia awal (46-55 } \\
\text { tahun) }\end{array}$ & 18 & 17,8 \\
\hline $\begin{array}{l}\text { Lansia akhir } \quad \text { (56-65 } \\
\text { tahun) }\end{array}$ & 31 & 30,7 \\
\hline Manula (>65 tahun) & 44 & 43,6 \\
\hline \multicolumn{3}{|l|}{ Jenis Kelamin } \\
\hline Laki-laki & 38 & 37,6 \\
\hline Perempuan & 63 & 62,4 \\
\hline \multicolumn{3}{|l|}{ Pendidikan Terakhir } \\
\hline SD & 24 & 23,8 \\
\hline SMP & 34 & 33,7 \\
\hline SMA & 24 & 23,8 \\
\hline Sarjana & 19 & 18,8 \\
\hline \multicolumn{3}{|l|}{ Status Pekerjaan } \\
\hline IRT & 42 & 41,6 \\
\hline PNS/TNI/POLRI & 15 & 14,9 \\
\hline Pensiunan & 11 & 10,9 \\
\hline Lain-lain & 33 & 32,7 \\
\hline \multicolumn{3}{|l|}{ Edukasi } \\
\hline $\mathrm{Ya}$ & 95 & 94,1 \\
\hline Tidak & 6 & 5,9 \\
\hline \multicolumn{3}{|l|}{ Dukungan keluarga } \\
\hline $\mathrm{Ya}$ & 62 & 61,4 \\
\hline
\end{tabular}

\begin{tabular}{lll}
\hline Tidak & 39 & 38,6
\end{tabular}

Analisis diatas didapatkan bahwa pasien yang terdiagnosis diabetes melitus tipe 2 di Wilayah Kerja Puskesmas Gang Sehat Pontianak mayoritas manula (>65 tahun) yaitu 43,6\%. Lebih banyak berjenis kelamin perempuan yaitu $62,4 \%$. Pendidikan terakhir responden sebagian besar SMP yaitu 33,7\%. Status pekerjaan responden sebagian besar adalah IRT sebesar 41,6\%, mendapatkan edukasi minum obat sebesar $94,1 \%$, mendapatkan dukungan keluarga sebesar $61,4 \%$.

Tabel 2. Peran Fungsi Petugas Kesehatan

\begin{tabular}{lcc}
\hline $\begin{array}{l}\text { Peran Fungsi Petugas } \\
\text { Kesehatan }\end{array}$ & f & $\%$ \\
\hline Baik & 66 & 65,4 \\
Kurang Baik & 35 & 34,6 \\
\hline
\end{tabular}

Dari tabel 2 didapatkan hasil Peran Fungsi Petugas Kesehatan pada kategori baik sebanyak 66 orang dengan presentase $65,4 \%$ dan tidak baik sebanyak 35 orang dengan presentase $40 \%$.

Tabel 3. Kepatuhan Minum Obat Diabets Melitus

\begin{tabular}{lll}
\hline $\begin{array}{l}\text { Kepatuhan Minum Obat } \\
\text { Diabetes Melitus }\end{array}$ & f & \% \\
\hline Patuh & 20 & 19,8 \\
Kurang Patuh & 57 & 56,4 \\
Tidak Patuh & 24 & 23,9 \\
\hline
\end{tabular}

Dari tabel 3 didapatkan hasil kepatuhan minum obat diabetes melitus dengan kategori patuh sebanyak 20 orang dengan presentase $19,8 \%$, kategori kurang patuh 57 orang dengan presentase $56,4 \%$, dan kategori tidak patuh sebanyak 24 orang dengan presentase 23,9\%. Uji statistik yang digunakan Chi-Square.

Tabel 3.1 Alasan penderita DM tidak patuh minum obat berdasarkan kuesioner MMAS-8 


\begin{tabular}{ll}
\hline \multicolumn{1}{c}{ Alasan } & Presentase (\%) \\
\hline 1. lupa minum obat & $17,8 \%$ \\
2.Sengaja tidak minum obat & $15,8 \%$ \\
\hline
\end{tabular}

\begin{tabular}{ll}
\hline 3.Berhenti Minum Obat & $17,8 \%$ \\
4.Tidak Membawa obat & $51,5 \%$ \\
5.Tidak Minum obat & $14,9 \%$ \\
6.Merasa sudah sehat & $48,5 \%$ \\
7.Pengobatan mengganggu & $11,9 \%$ \\
8.Sulit mengingat minum & $10,9 \%$ \\
\hline
\end{tabular}

Hubungan Peran Fungsi Petugas Kesehatan dengan Kepatuhan Minum Obat pada Pasien Diabetes Melitus Tipe 2

Tabel 4. Hubungan peran fungsi petugas kesehatan dengan kepatuhan minum obat pada pasien diabetes melitus tipe 2

\begin{tabular}{|c|c|c|c|c|c|c|c|c|}
\hline \multirow{3}{*}{$\begin{array}{l}\text { Peran Fungsi } \\
\text { Kesehatan }\end{array}$} & \multicolumn{6}{|c|}{ Kepatuhan Minum Obat } & \multirow{3}{*}{ Total } & \multirow{3}{*}{$p$} \\
\hline & \multicolumn{2}{|c|}{ Tidak Patuh } & \multicolumn{2}{|c|}{ Kurang Patuh } & \multicolumn{2}{|c|}{ Patuh } & & \\
\hline & $\mathbf{F}$ & $\%$ & f & $\%$ & $\mathbf{f}$ & $\%$ & & \\
\hline Kurang baik & 10 & $9,9 \%$ & 16 & $15,8 \%$ & 9 & $8,9 \%$ & 35 & 0,278 \\
\hline Baik & 14 & $13,9 \%$ & 41 & $40,6 \%$ & 11 & $10,9 \%$ & 66 & \\
\hline Total & 24 & $23,8 \%$ & 57 & $56,4 \%$ & 20 & $19,8 \%$ & 101 & \\
\hline
\end{tabular}

Dari hasil uji statistik Chi-Square diperoleh nilai $p$ value sebesar 0,278 ( $\mathrm{p}$ $>0,05)$, kesimpulan bahwa tidak terdapat hubungan peran fungsi petugas kesehatan dengan kepatuhan minum obat pada pasien diabetes melitus tipe 2 di Wilayah Kerja Puskesmas Gang Sehat Pontianak.

\section{PEMBAHASAN}

Karakteristik responden yang digunakan pada penelitian ini adalah usia, jenis kelamin, pendidikan terakhir, status pekerjaan, data edukasi, dan datadukungan keluarga. Pasien yang mengalami penyakit diabetes melitus pada penelitian ini dari kategori dewasa akhir sampai masa manula dan mayoritas rata-rata usia responden yang menderita diabates melitus berada dalam kategori manula usia $>65$ tahun $(43,6 \%)$.

Usia merupakan faktor spesifik yang dapat meningkatkan penimbunan lemak dalam tubuh yang dapat mengganggu kerja insulin serta dapat menyebabkan terjadinya kecacatan pada sel beta pancreas sehingga menimbulkan adanya retensi insulin. Ketika terjadi retensi insulin, maka akan terjadi penumpukan glukosa di dalam tubuh yang dapat menyebabkan terjadinya penyakit $\mathrm{DM}^{9}$.
Pada penelitian Mokolamban (2018) menyatakan bahwa pasien usia 1865 lebih patuh dalam mengonsumsi obat dibandingkan pasien usia >65 tahun, dimana pasien pada kelompok ini rata-rata juga sudah berusia lanjut yaitu 40 tahun ke atas yang merasa penting untuk menjaga kesehatannya ${ }^{11 .}$

Pengelompokan pasien berdasarkan jenis kelamin dilakukan untuk mengetahui perbandingan jumlah pasien laki-laki dan perempuan, hasil penelitian ini menunjukan bahwa mayoritas responden yang menderita diabetes melitus adalah perempuan. Perbedaan jumlah berdasarkan jenis kelamin ini sejalan dengan hasil penelitian Jelantik dan Haryati menunjukan bahwa penyakit diabetes melitus sebagian besar dapat dijumpai pada perempuan dibandingkan laki-laki. Hal ini dapat disebabkan karena pada perempuan memiliki LDL (Low Density Lipoprotein) yang lebih tinggi dibandingkan dengan laki-laki, dan juga terdapat perbedaan dalam melakukan semua aktivitas dan gaya hidup sehari-hari yang sangat mempengaruhi kejadian suatu penyakit, dan hal tersebut merupakan salah satu faktor ${ }^{11}$.

Pendidikan responden sebagian besar SMP (33,7\%). Orang dengan tingkat pendidikan tinggi akan lebih biasa 
menerima dirinya sebagai orang sakit jika mengalami gejala yang berhubungan dengan suatu penyakit dibandingkan dengan pendidikan rendah ${ }^{12}$. Pasien ditingkat pendidikan rendah menilai bahwa kesehatan merupakan suatu hal yang lebih penting, dengan patuh mengonsumsi obat maka akan membantu meningkatkan kesehatan ${ }^{11}$.

Masyarakat yang memiliki pendidikan yang lebih tinggi, umumnya mempunyai pengetahuan dan wawasan yang lebih luas sehingga lebih mudah menyerap dan menerima informasi. Sehingga dengan pengetahun yang diperoleh, maka klien akan mengetahui manfaat dan saran atau nasihat dari petugas kesehatan serta mereka akan lebih patuh dalam menjalani pengobatan ${ }^{13}$.

Karakteristik Pekerjaan responden sebagian besar ibu rumah tangga/ IRT $(41,6 \%)$, responden dengan pekerjaan IRT lebih beresiko terkena diabetes melitus karena mereka kurang dalam melakukan aktivitas fisik hal ini dapat dibuktikan dengan pekerjaan mereka seperti memasak, menyapu, mencuci, dan lainlain dapat dilakukan dalam waktu yang singkat. Sedangkan waktu untuk bersantai lebih banyak seperti duduk-duduk, menonton dan lain-lain.

Karakteristik data edukasi responden sebagian besar mendapatkan edukasi minum obat diabetes melitus $(94,1 \%)$. Seseorang yang pernah mendapatkan edukasi akan memiliki pengetahuan yang lebih baik dibandingkan dengan yang belum pernah mendapatkan edukasi. Dimana edukasi tersebut memiliki pengaruh yang cukup besar untuk menentukan perilaku seseorang sebagai upaya menjaga kesehatannya. Sejalan dengan penelitian Sucipto \& Rosa menyatakan ada pengaruh kepatuhan setelah diberikan edukasi pada responden diabetes melitus. pemberian edukasi dan konseling inilah pasien diharapkan memiliki pengetahuan yang cukup tentang diabetes, yang selanjutnya dapat merubah sikap dan perilakunya ${ }^{14}$.
Karakteristik data dukungan keluarga sebagian besar mendapatkan dukungan keluarga dalam pengobatan diabetes melitus $(61,4 \%)$. Sejalan dengan penelitian Lenny \& Fridalina bahwa responden yang mendapatkan dukungan keluarga dinyatakan patuh dalam minum obat $^{15}$. Dukungan keluarga merupakan sikap, tindakan dan penerimaan terhadap penderita yang sakit. Penderita DM sangat memerlukan dukungan sosial dari orang lain selama menjalani proses pengobatanya. Penelitian ini berlawanan dengan yang dilakukan oleh Oktaviani, Widagdo \& Widjanarko yang menemukan bahwa tidak ada hubungan dukungan keluarga dengan kepatuhan pengobatan pada penderita diabetes melitus ${ }^{16}$.

Peran fungsi petugas kesehatan di UPTD Puskesmas Gang Sehat Pontianak dinyatakan baik. Peran fungsi petugas kesehatan sebagai pemberi pelayanan kesehatan, edukator dan konselor yakni dokter, perawat, dan apoteker mempunyai tugas masing-masing. Peran dokter memberikan edukasi berupa informasi minum obat dan mengingatkan kontrol pada pasien DM. Peran perawat melakukan pengkajian pada pasien DM, mengingatkan kontrol, memberikan edukasi informasi minum obat, dan menyarankan untuk cek gula darah. Peran Apoteker memberikan penjelasan berupa obat diabetes yang dikonsumsi.

Dukungan yang dapat diberikan oleh petugas kesehatan kepada pasien terdiri empat jenis dukungan. Dukungan pertama adalah dukungan informasional yaitu dalam bentuk pemberian informasi, nasihat, ide, arahan dan lainnya yang dibutuhkan. Dukungan kedua yaitu dukungan emosional untuk rasa damai dan aman berupa simpatik, empati, kepercayaan, perhatian dan cinta. Dukungan ketiga berupa dukungan instrumental seperti memberikan peralatan lengkap, obat-obatan dan lain-lain yang dibutuhkan. Sementara dukungan keempat ialah dukungan penilaian dalam bentuk pemberian penghargaan atau apresiasi. 
Dukungan tersebut diperoleh dari dokter, perawat maupun petugas kesehatan lainnya ${ }^{17}$.

Kepatuhan Minum Obat diabetes di UPTD Puskesmas Gang Sehat Pontianak dinyatakan kurang patuh. berdasarkan kuesioner MMAS-8 alasan sebagian besar pasien tidak patuh minum obat diabetes adalah pasien tidak membawa membawa obat ketika berpergian jauh (51,5\%), alasan tidak membawa obat bisa karena lupa, semakin tua usia seseorang maka fungsi kognitif akan semakin berkurang, sehingga mempengaruhi dari tingkat keberhasilan pengobatan.

Penelitian yang dilakukan di Wilayah Kerja Puskesmas Gang Sehat Pontianak didapatkan bahwa tidak ada hubungan peran fungsi petugas kesehatan dengan kepatuhan minum obat pada pasien diabetes melitus tipe 2 .

Hasil penelitian ini sejalan dengan penelitian yang dilakukan oleh Oktaviani, Widagdo, \& Widjanarko yang menunjukan bahwa tidak ada hubungan dukungan petugas kesehatan dengan kepatuhan pengobatan penderita diabetes melitus di Puskesmas Pudak Payung Kota Semarang $(\mathrm{p}=0,578)^{16}$. Lenny \& Fridalina menyatakan tidak ada hubungan peran tenaga kesehatan dengan kepatuhan berobat jalan, peran serta dukungan petugas kesehatan sangatlah besar bagi penderita, dimana petugas kesehatan adalah pengelola penderita dan petugas adalah yang paling sering berinteraksi, sehingga pemahaman terhadap kondisi fisik maupun psikis menjadi lebih baik dan dapat mempengaruhi rasa percaya dan menerima kehadiran petugas kesehatan dapat ditumbuhkan dalam diri penderita dengan baik ${ }^{15}$.

Hal yang dapat dilakukan oleh petugas kesehatan adalah membantu pasien agar tidak lupa minum obat antara lain memberikan alat bantu seperti kartu pengingat minum obat yang dapat ditandai bila pasien sudah meminum obat, memberikan informasi tambahan atau tulisan yang besar dan jelas pada etiket obat untuk pasien yang sulit mendengar atau melihat, memberikan dukungan, motivasi, serta memberikan kemudahan dalam upaya pengobatan.

Selain peran dari petugas kesehatan, perilaku kesehatan individu juga dipengaruhi oleh motivasi diri individu untuk berperilaku yang sehat dan menjaga kesehatannya. Motivasi merupakan suatu proses psikologis yang mencerminkan interaksi antara sikap, kebutuhan, persepsi, dan keputusan yang terjadi pada diri seseorang, dan motivasi sebagai proses psikologis timbul diakibatkan oleh faktor di dalam diri seseorang itu sendiri yang disebut dengan faktor intrinsic atau faktor di luar dirinya disebut faktor ekstrinsik ${ }^{5}$.

\section{SIMPULAN SARAN}

Hasil penelitian ini didapatkan nilai p 0,278 yang berarti tidak terdapat hubungan peran fungsi petugas kesehatan dengan kepatuhan minum obat pada pasien diabetes melitus tipe 2 di Wilayah Kerja Puskesmas Gang Sehat Pontianak.

Diharapkan pada peneliti selanjutnya dapat dilakukan penelitian lanjut dengan metode yang berbeda atau dengan pendekatan kualitatif. Perlu kiranya melakukan penelitian serupa ditempat lain dengan kondisi daerah dan Puskesmas yang berbeda, serta sampel yang lebih luas agar penelitian tersebut lebih representatif dan lebih valid.

\section{DAFTAR PUSTAKA}

1. Kementerian Kesehatan RI. (2014). Infodatin Situasi dan Analisis Diabetes. Jakarta.

2. Bulu, A., Wahyuni, T. D., Sutriningsih, A. (2019). Hubungan Antara Tingkat Kepatuhan Minum Obat Dengan Kadar Gula Darah Pada Pasien Diabetes Melitus Tipe 2. Nursing News. 4(1), 181-189.

3. Putra, I. W. A., Berawi, K.N. (2015). Empat Pilar Penatalaksanaan Pasien Diabetes Mellitus Tipe 2. Majority. 4(9), 8-12. 
4. Kementerian Kesehatan RI. (2018). Riset Kesehatan dasar 2018.

5. Tombokan, V., Rattu, A. J. M., Tilaar, C. R. (2015). Faktor-faktor yang Berhubungan dengan Kepatuhan Berobat Pasien Diabetes Melitus pada Praktek Dokter Keluarga di Kota Tomohon. JIKMU. 5(2), 260-269.

6. Jilao, M. (2017). Tingkat Kepatuhan Penggunaan obat antidiabetes oral pada pasien diabates melitus di puskesmas koh-libong thailand. Malang: Universitas Islam Negeri Maulana Malik Ibrahim. Skripsi S1.

7. Hestiana, D.W. (2017). Faktor-faktor yang Berhubungan dengan Kepatuhan dalam Pengelolaan Diet pada Pasien Rawat Jalan Diabetes Melitus Tipe 2 di Kota Semarang. Journal of Healt Education. 2(2), 138-145

8. Perkumpulan Endrokrinologi Indonesia (PERKENI). (2015). Konsensus Pengelolaan Dan Pencegahan Diabetes Melitus Tipe 2 Di Indonesia 2015. PB. Perkeni, Jakarta

9. Purwandari, H. (2017). FaktorFaktor yang Mempengaruhi Kepatuhan Klien Diabetes Melitus dalam Menjalankan program Terapi DM. STIKes Satria Bhakti Nganjuk.

10. National Institude of Health.(2014). Insuline Resistence and Prediabetes.The National Diabetes Clearinghouse.

11. Mokolamban, C., Wiyono, W.I., \& Mpila, D. A. (2018). Kepatuhan Minum Obat pada Pasien Diabetes Melitus Tipe 2 disertai Hipertensi dengan Menggunakan Metode MMAS-8. Jurnal Ilmiah Farmasi. 7(4), 69-78.

12. Jelantik, I.M.G. \& Haryati, E. (2014). Hubungan Faktor
ResikoUmur, Jenis Kelamin, Kegemukan dan Hipertensi dengan Kejadian Diabetes Melitus Tipe II di Wilayah Kerja Puskesmas Mataram.Media Bina Ilmiah. 8(1), 39-44

13. Isnaini, N., Ratnasari. (2018). Faktor Resiko Mempengaruhi Kejadian Diabetes Melitus Tipe 2. Jurnal Kebidanan dan Keperawatan Aisyiyah. 14(1), 59-68

14. Ahda, M. H. (2016). Pengaruh Tingkat Pendidikan dan Dukungan Keluarga terhadap Tingkat Kepatuhan Minum Obat pada Pasien Hipertensi di Rumah Sakit Umum Daerah Kajen Kabupaten Pekalongan. Semarang: Universias Muhammadiyah Semarang. Skripsi S1.

15. Sucipto, A. \& Rosa, E. M. (2018). Efektivitas Konseling DM dalam Meningkatkan Kepatuhan dan Pengendalian Gula Darah pada Diabetes Melitus Tipe 2. Muhammadiyah Journal of Nursing. 9-20

16. Lenny \& Fridalina. (2018). FaktorFaktor yang Berhubungan dengan Kepatuhan Berobat Jalan Pasien Diabetes Melitus Tipe 2. Jurnal Ilmu Kesehatan Masyarakat, 85-93

17. Oktaviani, B., Widagdo, L. \& Widjanarko, B. (2018). Faktor yang Berhubungan dengan Kepatuhan Penderita Diabetes Melitus dalam Menjalani Pengobatan di Puskesmas Pudak Payung Kota Semarang. Jurnal Kesehatan Masyarakat. 6(5), 713-720

18. Violita, F. (2015). Faktor yang Berhubungan dengan Kepatuhan Minum Obat Hipertensi di Wilayah Kerja Puskesmas Segeri. Makassar: Universitas Hasanuddin. Skripsi S1. 